
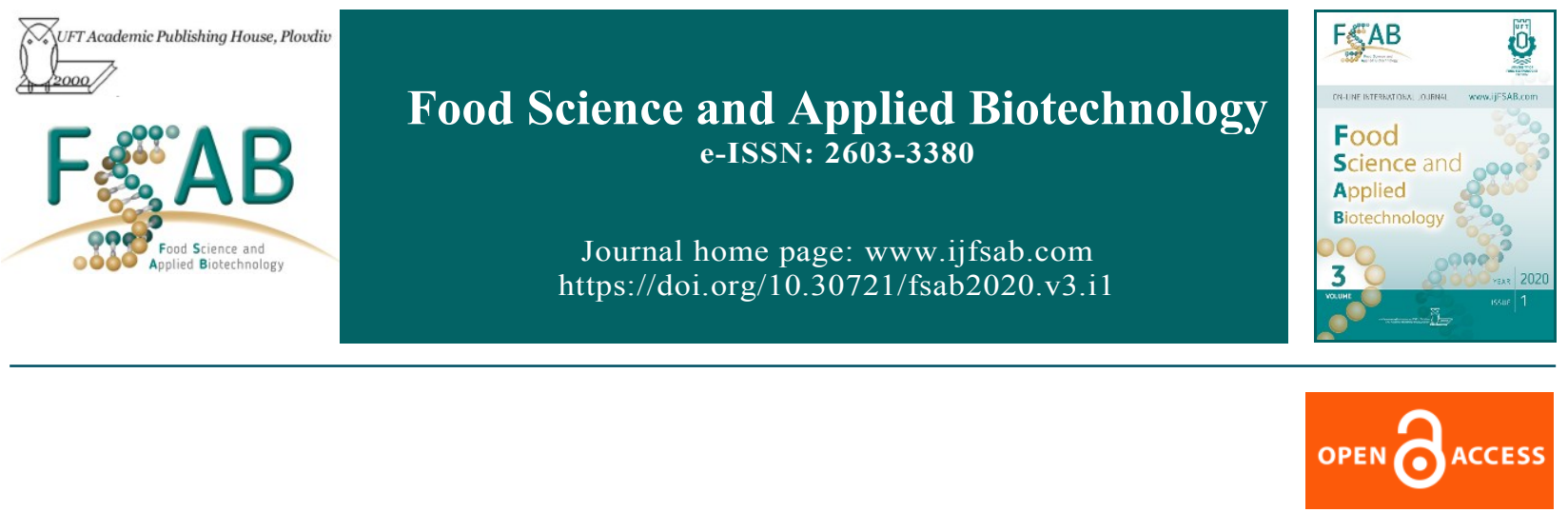

Review

\title{
Low-temperature cooking method "Sous-vide" in the restaurant industry: A review
}

\author{
Stanko Stankov ${ }^{1 \varpi}$, Hafize Fidan ${ }^{1}$, Rusiyan Rusev ${ }^{1}$, Marianna Baeva ${ }^{1}$ \\ ${ }^{1}$ Department of Catering and Tourism, Business Faculty, University of Food Technologies, Plovdiv, Bulgaria
}

\begin{abstract}
This article summarizes the basic techniques, changes in quality indicators of meat, fish and vegetable foods concerning the food safety, and the science of "Sous-vide" cooking. The material is a critical analysis of the pros and cons of using the ,sous-vide“ method. This review aimed to summarize the possibilities and to address some of the major problems that may arise from the use of the method. The review mentions the individual steps and technological solutions for low-temperature processing. The material can be used as a guide by food specialists, catering workers, and households.
\end{abstract}

Keywords: "Sous-vide", low-temperature cooking, quality and safety foods

${ }^{\square}$ Corresponding author: Assistant Prof. Eng. Stanko Stoyanov Stankov, Ph.D.; University of Food Technologies, Faculty of Economy, Department of Catering and Tourism, Plovdiv, 26 Maritza Blvd., Bulgaria, tel.: +359884127770, E-mail: docstankov@gmail.com

Article history:

Received: 16 September 2019

Reviewed: 21 October 2019

Accepted: 29 October 2019

Available on-line: 19 March 2020

https://doi.org/10.30721/fsab2020.v3.i1.83 (C) 2020 The Authors. UFT Academic publishing house, Plovdiv

Stankov et al., 2020 Low-temperature cooking method "Sous-vide"... 


\section{Introduction}

Modern cooking, both in specialized restaurants and home cooking, has undergone significant changes around the world. Today, more than ever, we can see industrial equipment in restaurants and households as an innovative and modern sign-on technology. Many cultures and ethnic groups around the world prepare their traditional dishes at low temperatures (Roca and Bruges 2005), mainly used to create richer aromatic characteristics of the dishes. The various nations prepare roast meats wrapped in leaves, put in clay pots, ovens, holes in the ground filled with ashes and embers (Anders et al. 2015).

A technique "Sous-vide" has been used for hundreds of year. Today, it is a modern method of cooking in a vacuum with relatively low-temperature processing for a long time (Creed 1998; Baldwin 2012; Roldán et al. 2015). After production, the packed food is cooled in cold baths and stored.

Used as a culinary technique, sous-vide has been widely used in European restaurants over the last decade (Myhrvold et al. 2011a,b). Today, a large number of famous culinary experts apply the method in some of the most famous restaurants around the world.

The sous-vide method is different from traditional culinary treatment. Here, the food is packaged in polyethylene packaging and vacuumed and then subjected to low-temperature heating usually at low temperatures 55-60 ${ }^{\circ} \mathrm{C}$, for an extended time $-72 \mathrm{~h}$ (Bryony and Yang 2012), then rapid (shock) cooling was applied to enhance the shelf life of the product.

Most often, the technique is applied in large culinary industries, centralized culinary production and, to a lesser extent, in themed „A la carte" restaurants.

In addition to the technological effects associated with the quality of culinary products, the method is also economically feasible. The use of online management, artificial intelligence via smart devices allows for the establishment of a coordinated process control system. Increasingly, some of the operations, such as controlling culinary processing parameters (time, temperature), can be controlled remotely.

The determination of the basic parameters of cooking time and temperature depend on the composition of the raw materials and the desired quality indicators of the finished products. Using the method, the raw materials are heated in a water bath and do not come into contact with the heat carrier. The temperature of the fluid (water) in the water bath is a few degrees higher than the desired temperature in the center of the product (Baldwin 2008). This, in turn, can cause superficial coagulation and digestion of the product.

In culinary practice, the method ,sous-vide" is applied according to two basic models: in the first case, the products are raw and subjected to evacuation and heating, in the latter case, the products are preblanched or partially prepared (frying, blanching, stewing). In both methods, the composition and the desired degree of culinary preparedness of the product should be considered. When using the method of producing mixed-composition meals (more than two products), the processing time and the processing temperature required to produce simultaneous culinary preparation should be refined.

According to other researchers (Vaudagna et al. 2002; Wang et al. 2004; Baldwin 2012), the method ,sousvide" the products are heated slowly and evenly. When placed in a vacuum environment, they retain their aromatic composition and the substances that determine their oxidative stability.

According to others (Church and Parsons 2000; Schafheitle 1992), the use of the method "sous-vide" provides higher quality meat products such as juiciness, fragility, taste and more.

Today, more than ever, the method is well accepted by specialists, as it creates conditions for better control of culinary processing - time, temperature and maintaining a consistent quality of culinary products. Vacuum cooking reduces the risk of contaminants from entering the environment.

Finding appropriate treatment regimes through "sousvide" is of great interest to researchers, as many dishes are prepared by applying several different heat treatments.

In another respect, the lower loss of meat juices during heat treatment can be taken into account by applying the method "sous-vide" The higher juiciness and tenderness of meat dishes can be taken into account (Church and Parsons 2000; Jouki and Khazaei 2011).

According to other authors (Hansen et al. 1995; Hansen and Knosel 1996; Schellekens 1996; Vaudagna et al. 2002; Bryony and Yang 2012), the precision culinary processing applied by the method "sous-vide" provides longer storage and preservation of the quality of meat culinary products.

Combining different raw materials reduces heat conduction and low heat treatment, and even for a long time can cause some undesirable processes - gas evolution or fermentation during storage. 
The aim of this study was to observe the specifications of the development of the "sous-vide" method in culinary production.

\section{"Sous-vide" cooking of vegetables}

The method of "Sous-vide is widely applicable in the treatment of various types of vegetables.

In ordinary boiling in water, nutrient-rich fruits and vegetables lose a great deal of them by passing into the fluid (fluid) (Bernard et al. 2015). In other plant species, the high temperature and rapid boiling of the liquid caused the destruction of the cellular structure and the oxidation of some biologically active components.

Unlike the traditional methods of food preparation, vegetables cooked through the method of "sous-vide", retain almost all their nutritive value. The application of the method for culinary processing of vegetables can retain much of the aromatic substances in the system, thus improving the organoleptic evaluation.

According to Buckley (1987a; 987b), using the broccoli brewing method at 5 days storage, $86 \%$ of vitamin $\mathrm{C}$ is better preserved than in broccoli blanched in water. This can be explained by the destruction of the superficially located cell walls and the occurrence of oxidative princesses inside the plant cell (Baldwin 2011)

The direct heating of vegetables in water causes diffusion processes associated with significant nutrient losses, discoloration and the biologically active composition of the product.

Other studies (Baldwin 2011) proved that broccoli, whole and sliced, boiled directly in water, may lose $(28 \%)$ and under pressure $(62 \%)$ of their color, and at 5 day-storage lose $9.4 \%$ and $7.3 \%$ of their color.

The preparation of vegetables with a high starch content can also be carried out at lower temperatures $\left(80^{\circ} \mathrm{C}\right)$ since carrot cooking can be used as it provides a uniform dissolution of the pectin and a uniform culinary readiness (Hong et al. 2015). Care should be taken of the thickness of the carrot layer to be processed, as well as the difference in it is optimal for the starch gelling (Garcia-Segovia et al. 2007). Keeping the temperature at $80-85^{\circ} \mathrm{C}$ ensures a uniform swelling of the starch grains and a uniform penetration of the liquid through their pores. This produces uniform gelatinization and desired culinary readiness.

Mixing of varietal and batch vegetables should be taken into account when using low-temperature cooking.
Patras et al. (2009) reported that using the method "sous-vide" for cooking of carrots, the amount of carotenoids during storage is more preserved than samples boiled in water.

Werlein (1998) reported that while storing carrots cooked by the "sous-vide" method, they have higher levels of $\alpha$ and $\beta$ carotene compared to samples treated with water and stored under the same conditions. The preservation of carotenoids may be due to the preservation of the cell surface structure and the inability of water to pass directly through the cell walls. This, in turn, preserved the color and nutrients in the product.

Other studies (Rawson et al. 2010) of spinach boiling in vacuum packaging have found that polyacetylene levels were lower than spinach boiled directly in water. when boiling in water, the shelf life of spinach is reported to be 5 days, while using the "sous-vide" method of storage was 21 days.

The retention of larger quantities of water in the product during ordinary cooking is a prerequisite for shorter shelf life. The inability of water from the environment to penetrate the intracellular structure of vegetables by the "sous-vide" method allows for a longer storage process.

No significant differences were reported for chicory compared to boiling in water and boiling in vacuum packaging (Renna et al. 2014).

Most sensory evaluations and comparisons of cooked vegetables by the "sous-vide" method were rated higher than cooked in water, steam, and pressure.

In vegetables rich in starch, such as beans, peas, lentils, maize, potatoes, the application of the "sousvide" method leads to the formation of a uniform culinary readiness when finely pasteurized starch in their composition (Baldwin 2011).

Hong et al. (2015) reported that when boiling beans at $90^{\circ} \mathrm{C}$, it absorbed the same amount of water as it did at room temperature for 16 hours.

The quality of water used for cooking beans effected on the degree of boiling. When using hard water (rich in minerals), boiling is slowed down. The acidic aqueous medium also slowed down the boiling as it strengthens the pectin structure. When using soft water with the addition of sodium chloride, magnesium was displaced from the pectin structure and helped to dissolve the fibers.

Numerous scientific evidence and practical advice prove the rationality of the "sous-vide" method in the heat treatment of several vegetables. The benefits in 
terms of color, aroma, texture, taste, and bioactive potential of vegetables have been proven.

\section{"Sous-vide" cooking of fish and fish products}

The consumption of fish and seafood on the human menu is increasing. Increased intake of fishery products was reported mainly in coastal areas where fish play the role of traditional food. Fish preparation in the restaurant is related to pretreatment (cleaning of flakes, entrails, flying, cutting). For other seafood delicacies, pretreatment is specific, related to the anatomical features of the species.

The heat treatment regimes of fish and seafood differ from those of other meats. They are mainly used in sparing modes of culinary processing. In the "sousvide" method, the most commonly used temperature is $46-49{ }^{\circ} \mathrm{C}$. Fish flakes were converted into gelatin at around $46-49^{\circ} \mathrm{C}$ (Belitz et al. 2004).

The application of the "sous-vide" method to fish processing preserves the fatty acid composition of the product (Ghazala et al. 1996), more so than traditionally cooked fish.

Testing of salmon fillet prepared under vacuum by the "sous-vide" method showed microbiological stability and high sensory evaluation at 6 months storage (González-Fandos et al. 2005; Díaz et al. 2009).

Picouet et al. (2011) demonstrated that using a pressure of $310 \mathrm{MPa}$ provided higher microbiological stability and better sensory evaluation for 6-8 days than using a pressure of 210 and $400 \mathrm{MPa}$.

González-Fandos et al. (2005) concluded that treatment at $90{ }^{\circ} \mathrm{C}$ in 33 minutes significantly improved the microbiological stability and sensory performance of trout (Oncorhynchus mykiss) fillet.

The application of culinary processing of fish and seafood by the "sous-vide" method can improve the expansion of the assortment in the restaurant menu. On the other hand, the method allowed for higher productivity by processing larger quantities of fishery products. This may be a prerequisite for the consumption of processed fresh fishery products reaching the consumer in a short time. The method allowed to maintain a constant quality of the end products, which positively influenced the consumer evaluation and stimulates the consumption of fishery products prepared by the "sous-vide" method (Souza 2002).

According to another researcher (Garsia-Linares et al. 2004) trout fillet prepared by the "sous-vide" method retained its acid composition for $20-45$ days stored at
0-4 ${ }^{\circ} \mathrm{C}$. Such studies (Díaz et al. 2009) proved the preservation of $\omega-3$ in salmon fillets during storage, compared to fillet processed using traditional techniques.

The sensory qualities of salmon fillet prepared by the "sous-vide" method for 100 days of ice storage at $0{ }^{\circ} \mathrm{C}$ were investigated. The positive effect of processing on nutritional composition and sensory perception has been demonstrated (Gittleson et al. 1992).

By applying the "sous-vide" method cooks can effectively regulate and monitor the temperature of the product. This makes it possible to achieve the desired texture of fish and seafood, which is difficult to adjust under traditional heating.

The high water content, the presence of enzyme systems and the relatively close nutritional composition of fish meat are a prerequisite for the development of many psychrophilic and mesophilic microorganisms. For this reason, the use of the "sousvide" method must be carried out with precision, the fish raw materials to be kept fresh with good sanitary and hygiene indicators (Picouet et al. 2011).

Some microbial stability tests need to be conducted to specify specific processing parameters. The different formulations of dishes incorporating fishery products need to be individually examined in order to determine storage standards for food safety.

\section{"Sous-vide" cooking of chicken}

Poultry is a vast category that encompasses leaner birds (chickens and turkeys), fattier waterfowl (ducks and geese), and smaller birds (quail, pheasants, squab, and guineafowl).

Poultry meat has become increasingly widespread in the human table. The peculiarities associated with its extraction (microbial contamination) have a great influence on the choice of processing parameters "sous-vide" (Khan and Van Den Berg 2006).

In addition to microbial stability, poultry meat is less volatile than oxidative processes (Nishimura et al. 2004). This necessitates the application of culinary processing methods to preserve its quality for longer shelf life.

The high water content and lower levels of collagen proteins allow the application of the "sous-vide" method for the thermal treatment of various anatomical parts of birds.

Differences in the composition of the individual anatomical parts (fats, proteins) influence the choice of processing parameters. In turn, the amount of fat, 
affect the oxidative stability and sensory performance of the chicken meat (Wang et al. 2004).

Some authors (Hong et al. 2015; Khan and Van Den Berg 2006; Sampaio et al. 2012) have examined the physical and sensory characteristics of chicken breast. They proved that the meat cooked "sous-vide" the method better retained its moisture during storage $\left(4^{\circ} \mathrm{C}\right)$ for 14 days. This is confirmed by the reported values of succulence recorded by the high moisture levels of $60-70 \%$.

A possible explanation for the lower moisture loss during heat treatment may be related to the vacuum packaging. Creating a mechanical barrier, the packaging does not allow moisture to escape, despite prolonged heating. On the other hand, the water retention effect can be explained by the slow and uniform heating, which allows gentle coagulation of muscle proteins.

Wang et al. (2004), reports that using the "sous-vide" chicken wings method extended their shelf life up to 7 weeks stored at $2^{\circ} \mathrm{C}$ this demonstrates relatively high fat stability and preservation of sensory performance.

Church (1990) reported an assessment of consumer quality and a comparison of different traditional meat dishes, sausages prepared by the „sous-vide" method. The analysis confirmed the high consumer rating regarding the juiciness of the meat and the quality of the dishes.

Smith and Fullum-Bouchard (1990) compared chicken meat prepared with different sauces during storage at days 1,3 and 6 at 4 and $-14^{\circ} \mathrm{C}$. From the analysis, they found no significant difference in the aroma, taste, and texture of the chicken.

Others (Levy 1986; Manser 1988) analyze the combination of chicken and duck meat with vegetables cooked by the method. No negative sensory effects from processing were reported.

Low sensory ratings have been reported in some fish mousse and poulet chasseur but unfavorably on vegetable dishes (Levy 1986).

The combination of several technological treatments in the production of traditional dishes leads to a dish with certain sensory characteristics. Under normal heating, some of the volatile substances are separated from the products. Others increased their concentration in the volume of the dish. For this reason, some sensory differences in individual dishes are also reported.

\section{"Sous-vide" cooking of pork and beef}

Red meat is used extensively on the menu of the population from the Balkan countries and some European countries. Traditional dishes prepared with them are distinguished by specific methods of culinary processing. The characteristics of pork, lamb, mutton, kid, goat, veal, beef, horses, big game are distinguished by higher values of connective tissue proteins. The chemical composition of these meats proteins $-20 \%$; fat $-5 \%$; water $75 \%$, varies within a narrow range, depending on age, sex, nutrition, breed, breeding style, and others.

When heated in the presence of fluid (water, water vapor, fat), the meat undergoes significant changes in its composition. The processes related to the denaturation of muscle proteins and changes in their fibrillar structure shape the quality of finished meat products.

During the heat treatment, the muscle fibers contract and transverse. The sarcoplasmic proteins aggregate and the connective tissue proteins dissolve in the form of a liquid gel.

Aggregation of sarcoplasmic proteins and initial dissolution of collagen proteins begin at $40{ }^{\circ} \mathrm{C}$ and finishes at around $60{ }^{\circ} \mathrm{C}$ (Sun and Holley 2010; Berhe et al. 2013), which largely determines the culinary readiness of the meat. Significant changes in the structure of muscle proteins are observed at temperatures above $65^{\circ} \mathrm{C}$.

Culinary processing of meat in a water bath (,,sousvide") promotes the gentle coagulation of proteins and the prolonged dissolution of binding proteins. The slow heating of the muscle cells conserves the water in the sarcoplasm and lends the meat to culinary products.

The relatively low heating $\left(35-40^{\circ} \mathrm{C}\right)$ of the muscle fibers slowed down their gross contraction (Baldwin 2012), and formed a delicate texture of the muscles, with fluid (fat, water) in the form of protein sol in the intracellular space.

According to Laakkonen et al. (1970), the water retention capacity of meat during heat treatment is determined by the rate of heating and temperature. With slow heating for a long time, the protein hydrated and increased its total surface area, with $80 \%$ of the water retained falling into the myofibrils between thin actin filaments and thick myosin fibers.

The longitudinal contraction of the muscle fibers in the range of $45-55^{\circ} \mathrm{C}$ allowed the cell fluid to be retained, 
and at temperatures above $60-65^{\circ} \mathrm{C}$, it is pushed out as the fibers contract transversely.

Sarcoplasmic proteins are mainly composed of enzymes and myoglobin. They exhibited significant swelling at $40-50^{\circ} \mathrm{C}$, in which they increase their surface area and turned into a gel-like sponge. In this structure, they retained a large amount of cellular juice that is in a tightly bound state. This process occurred in the initial stages of heating and significantly improved the juiciness also determined the color of the meat (Berhe et al. 2013).

Collagen proteins, located on the surface of muscle fibers, started to degrade most intensely over $65^{\circ} \mathrm{C}$. The destruction of the triple helix of collagen filaments by heat treatment turned them into arbitrarily folded collagen proteins that dissolve and turn into gelatin (Roldán et al. 2013)

The change in elastin fibers structure is different from that of collagen. Because they are less quantitative, they are not critical to the degree of culinary readiness of the meat. First of all, for the sake of the safety of meat culinary products, the lowest temperature that applied is $55^{\circ} \mathrm{C}$ which underlies the denaturation of collagen proteins (Roldán et al. 2015).

Depending on the degree of culinary preparedness desired, several cooks recommended that the beef, pork, or lamb heating temperature be at least $58-63^{\circ} \mathrm{C}$ for 10-48 hours (García Segovia et al. 2007).

Mortensen et al. (2012) reported that at $56^{\circ} \mathrm{C}$ for 12 hours ("sous-vide" cooking), higher-valued veal ( $M$. semitendinosus) was cooked than at $58{ }^{\circ} \mathrm{C}$ and $60{ }^{\circ} \mathrm{C}$ for 3, 6 and 9 hours.

While for lamb ( $M$. longissimus thoracis et $M$. lumborum), the best temperature and time interval was indicated at 70 for 24 hours. The use of higher temperatures for a shorter time and lower temperatures for a longer time results in meat with a dry cut surface and a fibrous structure (Roldán et al. 2013).

According to García Segovia et al. (2007) application of "sous-vide" cooking for 45 minutes at $80^{\circ} \mathrm{C}$ and 60 minutes at $70^{\circ} \mathrm{C}$ exhibits better textural characteristics than meat prepared using traditional techniques.

Vaudagna et al. (2002) proved that applying "sousvide" the bovine semitendinosus method at temperatures of $50-65^{\circ} \mathrm{C}$ for 6.5 hours did not significantly change the texture from that prepared for 1.5 hours.

Probably the time and temperature for the preparation of the meat by the ,sous-vide" method depended on the quantity and quality of the connective tissue proteins included in the meat composition (Christensen et al. 2013).

By applying the ,sous-vide" method with the consideration that semitendinosus muscle from young bovine for 2.5 hours at a temperature of $53^{\circ} \mathrm{C}$ produces meat with the best textural and sensory characteristics compared to cooking at higher temperatures $(55,58$ and $63^{\circ} \mathrm{C}$ ) for a longer time (Christensen et al. 2013).

Studies have also confirmed that the increasing temperature and treatment time of the method could cause a decrease in succulence (Mortensen et al. 2012).

Others (Roldán et al. 2013; Berhe et al. 2013; James et al. 2012) have found that the loss of meat juices depended more on the choice of high heating temperature than on the holding time. They confirm that high temperature for a short time could cause more loss of lushness than a lower temperature in a shorter time.

The microstructure of meat prepared by the "sousvide" method showed that at $70^{\circ} \mathrm{C}$ muscle fibers had a more compact structure than those at $60^{\circ} \mathrm{C}$ and $80^{\circ} \mathrm{C}$ (Roldán et al. 2013).

There was a lower degree of muscle contraction in beef in the "sous-vide" method than traditional cooking in water (James et al. 2012).

Other authors (Christensen et al. 2013) have commented that at $53^{\circ} \mathrm{C}$ for 19.5 hours myosin and collagen peaks decreased, defining this as improved juiciness of meat from the bull (M. Semitendinosus) analyzed by differential scanning calorimetric analysis. The temperature and time used for the application of the method in the culinary practice of meat processing must be selected to ensure a high degree of collagen protein dissolution and minimal contraction of myofibrillar proteins (Roldan et al. 2015). On the other hand, temperature and time must be refined to ensure the microbial stability of the food.

Other researchers (Tomberg 2005) have discussed the juiciness of meat as an effect of the action of its enzymes when using lower cooking temperatures. According to them, gel formation in the intracellular spaces is a favorable effect, which determines the low values of force required for cutting or the juiciness of the meat after culinary processing.

The increased hardness of the meat after culinary treatment is reported by applying heating temperatures between $65-80^{\circ} \mathrm{C}$, while at temperatures in the range of $50-60^{\circ} \mathrm{C}$, this force is lower (Baldwin 2012). 
According to Werner (2016), the amount of thiamine and riboflavin is maintained at the highest levels in pork prepared by the „sous-vide" method. During a 21day storage process, $90 \%$ of the initial values after culinary processing were preserved.

Additionally, no changes are observed during storage to ensure a long shelf life of the vitamins. Besides, the released juice should always be further processed, i.e., in the preparation of a sauce, as the juice contains the "lost" water-soluble vitamins (Roldán et al. 2013).

\section{Microbiological hazards in "Sous-vide" foods}

In terms of food safety, foods prepared by the ,sousvide" method have been often discussed. The food is cooked under vacuum packed in polyethylene, which slowed down the heat transfer. The main problems were related to the attainable final temperature and to ensuring the microbiological stability of culinary products (Sheard and Rodger 1995; Armstrong and Mcllveen 2000).

From a microbiological point of view, attention was focused on microorganisms that can spore and develop in an oxygen-free environment. These were the most common representatives of Clostridium botulinum $\left(3.3^{\circ} \mathrm{C}\right.$ and $\left.45^{\circ} \mathrm{C}\right)$ in vacuum-packaged foods; Bacillus cereus and Clostridium perfringens $\left(4^{\circ} \mathrm{C}\right.$ and $\left.52.3^{\circ} \mathrm{C}\right)$, (Snyder 2003).

Several researchers (Juneja 2006; Oh et al. 2006; Renna et al. 2014) have shared the results on the microbiological stability of foods prepared by the "sous-vide" method and cook-chill method (Keller et al. 2008).

Some vegetative forms of Salmonella spp., pathogenic strains of Escherichia coli, Staphylococcus aureus, Yersinia enterocolitica, Listeria spp., could be adapted to the anaerobic environment. Others, such as Listeria spp. Yersinia enterocolitica could develop at low temperatures $\left(-1.5^{\circ} \mathrm{C}\right)$. The preservatives are not additionally used in culinary products. This further increases the risk of developing unwanted microorganisms during storage of the meals prepared by the "sous-vide" method.

The lower cooking temperature destroyed only the vegetative forms of microorganisms. The possibility of sealing or destroying the packaging exists. Anaerobic microorganisms such as Clostridium perfringens, Clostridium botulinum, and Bacillus cereus, and facultative anaerobes such as Listeria monocytogenes (Renna et al. 2014), are highly likely to develop during the storage.
The control over the application of the „sous-vide" method must be followed very strictly. Rapid cooling prevented the development of microorganisms during storage. All procedures for performing technological operations must be following the HACCP of the production concerned (Al-Qadiri et al. 2008). The question is whether any psychrotrophic pathogens (Yersinia enterocolitica, Clostridium botulinum) can survive despite rapid cooling.

One of the most dangerous foodborne bacteria is Clostridium botulinum, which produces toxins up to temperatures of $3.3^{\circ} \mathrm{C}$. Although it dies at temperatures of about $70^{\circ} \mathrm{C}$ foods need to be heated to $90^{\circ} \mathrm{C}$ for 10 minutes to eliminate its spores.

The use of a vacuum medium largely prevented oxidation processes (Baldwin 2012).

Nyati (2000) examined the microbiological status of some foods prepared by the "sous-vide" method and found that after processing, no traces of Listeria monocytogenes, Clostridium perfringens, Bacillus cereus, Salmonella, and other Enterobacteriaceae were detected.

Others (González-Fandos et al. 2004) use the ,sousvide" method to extend the shelf life $\left(45\right.$ days at $\left.2^{\circ} \mathrm{C}\right)$ of rainbow trout, with no microbial cells from Staphylococcus aureus, Bacillus cereus, Clostridium perfringens, and Listeria monocytogenes, found after treatment.

Similarly, (Shakila et al. 2009) demonstrated the microbial stability of sous-vide fish cakes during $\left(3^{\circ} \mathrm{C}\right)$ chilled, against Clostridium botulinum, Clostridium perfringens, and Bacillus spp.

Studies (Simpson et al. 1995; Brown 1990) of foods in which a large number of components are involved showed that some spore forms were present. This is probably due to the poor thermal conductivity of the individual foods in the system.

In recent years, some researchers (Juneja et al. 2006) have investigated the development of Clostridium perfringens in various culinary products prepared by the ,sous-vide" method. They find that the participation of $3 \%$ sodium chloride in the food composition decreased the spore outgrowth. For culinary products, this level of sodium chloride is too high. For this reason, it cannot be used as a factor for the preservation of culinary products. In some traditional meat foods with a salty taste, it can be applied. 
Other authors (Knochel et al. 1997; Aran 2001) suggested the use of calcium lactate and sodium lactate in various foods, thereby inhibiting Bacillus cereus. For better security, before serving, foods prepared must be reheated (Vijay et al. 1996).

\section{Conclusion}

The application of the ,sous-vide" method has increased significantly over the last decade. The biggest growth was seen in restaurants and catering establishments. The use of the method has both positive and negative sides. The preparation of a variety of culinary products, which include different products, created conditions for uneven and precise temperature monitoring. The "sous-vide" method is applicable in compliance with high hygiene and technological standards for quality assurance and food safety.

\section{References}

Al-Qadiri H.M., Lin M., Al-Holy M.A., Cavinato A.G. \& Rasco B.A. Detection of Sublethal Thermal Injury in Salmonella enterica Serotype Typhimurium and Listeria monocytogenes Using Fourier Transform Infrared (FTIR) Spectroscopy (4000 to $600 \mathrm{~cm}^{-1}$ ). Food Science, 2008. https://doi.org/10.1111/j.1750-3841.2007.00640.x

Anders D., Lawaetz J. \& Søren B. Accurate determination of endpoint temperature of cooked meat after storage by Raman spectroscopy and chemometrics. Food Control, 2015, 52: 119-125. https://doi.org/10.1016/j.foodcont.2014.12.011

Aran N. The effect of calcium and sodium lactates on growth from spores of Bacillus cereus and Clostridium perfringens in a 'sous-vide' beef goulash under temperature abuse. Journal of Food Microbiology, 2001, 63(1-2): 117-123.

https://doi.org/10.1016/S0168-1605(00)00412-8

Armstrong G.A. \& Mcllveen H. Effects of prolonged storage on the sensory quality and consumer acceptance of sous vide meat-based recipe dishes. Food Quality and Preference, 2000, 11(5): 377-385.

https://doi.org/10.1016/S0950-3293(00)00011-2

Baldwin D. A practical guide to sous vide cooking. 2011, http://www.douglasbaldwin.com/sous-vide.html

Baldwin D.E. A practical guide to sous vide cooking. 2008 http://www.douglasbaldwin.com/sous-vide.html

Baldwin D.E. Sous vide cooking: A review. International Journal of Gastronomy and Food Science, 2012, 1(1): 1530. https://doi.org/10.1016/j.ijgfs.2011.11.002
Belitz H., Grosch W., Schieberle P., Springer-Verlag \& Heideberg H. Food Chemistry, 2004, 1070. https://www.springer.com/us/book/9783540699330

Bernad I., Segovia G., Martínez P. \& Monzó, J. Physicochemical and structural characteristics of vegetables cooked under sous-vide, cook-vide, and conventional boiling. Journal of Food Science, 2015, 80(8): 1725E1734.

https://www.ncbi.nlm.nih.gov/pubmed/26130376

Berhe D.T., Hviid M.S., Engelsen S.B. \& Lametsch R. Use of raman spectroscopy to study effect of cooking temperature and time on meat proteins. Conference: 59 th International Congress of Meat Science and Technology, 2013.

https://www.ampc.com.au/uploads/cgblog/id84/2013.9501 -Development-and-validation-of-a-probe.pdf

Brown C. Gaze controls cooperating through prediction. Image and Vision Computing, 1990, 8(1): 10-17.

https://doi.org/10.1016/0262-8856(90)90050-F

Bryony J. \& Yang S.W. Effect of Cooking Method on the Toughness of Bovine M. Semitendinosus. International Journal of Food Engineering, 2012, (8): 2.

https://doi.org/10.1515/1556-3758.2762

Buckley C. Storage stability of vitamin $\mathrm{C}$ in a simulated sous-vide process. Hotel Catering Res. Centre Lab. Rep., 1987a, 240: 2.

https://www.sciencedirect.com/science/article/pii/0956713 59591453R

Buckley C. The vitamin C content of cooked broccoli. Hotel Catering Res. Centre Lab. Rep., 1987b, (238): 6. https://www.sciencedirect.com/science/article/pii/0956713 59591453R

Christensen L., Ertbjergc P., Løje H., Risbo J., Frans W. \& Christensena M. Relationship between meat toughness and properties of connective tissue from cows and young bulls heat treated at low temperatures for prolonged times. Meat Science, 2013, 9(4): 787-795.

https://doi.org/10.1016/j.meatsci.2012.12.001

Church I.J. and Parsons A.L. The sensory quality of chicken and potato products prepared using cook-chill and sous vide methods. International Journal Food Science Technology, 2000, 35(2): 155-162.

https://onlinelibrary.wiley.com/doi/abs/10.1046/j.13652621.2000.00361.x

Church LJ. An introduction to 'method sous-vide'. department of hospitality management. Leeds Polytechnic, 1990, 46. https://core.ac.uk/download/pdf/75025.pdf

Creed P.G. Sensory and nutritional aspects for sous vide processed food In: Sous Vide and Cook-Chill Processing for the Food Industry (edited by S. Ghazala). Gaithersburg, 1998, MD: Aspen.

http://www.technecalibration.com/adminimages/Sous Vid e Information(1).pdf

Díaz P., Gema Nieto G., Bañon S. \& Garrido M.D. Determination of shelf life of sous vide salmon (salmo 
salard) based on sensory attributes. Journal Food Science, 2009, (74): 371-376.

https://doi.org/10.1111/j.1750-3841.2009.01317.x

García-Linares M.C., Gonzalez-Fandos E., GarcíaFernández M.C. \& García-Arias M.T. Microbiological and nutritional quality of sous vide or traditionally processed fish: influence of fat content. Accepted For Publication April, 2004, 4.

https://onlinelibrary.wiley.com/doi/pdf/10.1111/j.17454557.2004.00676.x

García-Segovia P., Andrés-Bello A. \& Martínez-Monzó J. Effect of cooking method on mechanical properties, color and structure of beef muscle (M. pectoralis). Journal of Food Engineering, 2007, 80(3): 813-821.

https://www.infona.pl/resource/bwmeta1.element.elsevier$\underline{8681 b 6 \mathrm{~d} 2-165 \mathrm{a}-3539-8 \mathrm{~d} 16-224 \mathrm{a} 1 \mathrm{~d} 3573 \mathrm{cb}}$

Ghazala S., Aucoin J. \& Alkanani T. Pasterization effect on fatty acid stability in a Sous Vide product containing seal meat (Phoca ghoenlandica). Journal Food Science, 1996, 61: 520-523.

https://onlinelibrary.wiley.com/doi/abs/10.1111/j.13652621.1996.tb13147.x

Gittleson B., Saltmarch M., Cocotas P. \& Proud L. Quantification of the physical, chemical and sensory modes of deterioration in sous-vide processed salmon. Journal Food service System, 1992, (6): 209-232. https://scholarworks.sjsu.edu/cgi/viewcontent.cgi?referer= https://www.google.bg/\&httpsredir=1\&article=4311\&cont ext=etd theses

González-Fandos E., García-Linares M.C., VillarinoRodríguez A., García-Arias M.T. \& García-Fernández M.C. Evaluation of the microbiological safety and sensory quality of rainbow trout (Oncorhynchus mykiss) processed by the sous vide method. Food Microbiology, 2004, 21(2): 193-201. https://doi.org/10.1016/S0740-0020(03)00053-4

González-Fandos E., Villarino-Rodríguez A. \& GarcíaLinares M.C. Microbiological safety and sensory characteristics of salmon slices processed by sous vide method. Food Control, 2005, 16: 75-85.

https://doi.org/10.1016/j.foodcont.2003.11.011

Hansen T.B. \& Knøchel S. Thermal inactivation ofListeria monocytogenesduring rapid and slow heating in sous vide cooked beef. Letters in Applied Microbiology, 1996, 22: 425-428.

https://www.ncbi.nlm.nih.gov/pubmed/8695067

Hansen T.B., Knøchel S., Juncher D. \& Bertelsen G. Storage characteristics of sous vide cooked roast beef. International Journal of Food Science and Technology, 1995, 30: 365-378.

https://onlinelibrary.wiley.com/doi/abs/10.1111/j.13652621.1995.tb01384.x

Hong G.E, Kim J.H., Ahn S.J. \& Lee S.H. Changes in Meat quality characteristics of the sous-vide cooked chicken breast during refrigerated storage. Korean Journal Food Science, 2015, 35(6): 757-764.
https://www.ncbi.nlm.nih.gov/pmc/articles/PMC4726955/

Horowitz BZ. Botulinum toxin. Critical Care Clinics, 2005, 21(4): 825-39.

https://www.ncbi.nlm.nih.gov/pubmed/16168317

James B.J. \& Yang S.W. Effect of cooking method on the toughness of bovine $\mathrm{m}$. semitendinosus. International Journal Food Engenering, 2012, (8): 2.

https:/www.degruyter.com/view/j/ijfe.2012.8.issue2/1556-3758.2762/1556-3758.2762.xml

Juneja V.K. Delayed Clostridium perfringens growth from a spore inocula by sodium lactate in sous-vide chicken products. Food Microbiology, 2006, 23(2): 105-111. https://www.ncbi.nlm.nih.gov/pubmed/16942993

Jouki M. \& Khazaei N. Effects of storage time on some characteristics of packed camel meat in low temperature. International Journal Animal Veterinary. Advances, 2011, (3): 460-464.

https://pdfs.semanticscholar.org/3724/9dbcafa77745f9d29 7002f7161286ba251b9.pdf

Keller T., Benno J. \& Lee C. Cooking Sous Vide. New York: Artisan / Workman Publishing Company, 2008.

https://www.amazon.com/Under-Pressure-CookingThomas-Library/dp/1579653510

Khan A.W. \& Van Den Berg L. Changes in chicken muscle proteins during cooking and subsequent frozen storage, and their significance in quality. Journal Food Science, 2006, 30: 151-153.

https://onlinelibrary.wiley.com/doi/abs/10.1111/j.13652621.1965.tb00280

Knøchel S., Vangsgaard R. \& Johansen L.S. Quality changes during storage of sous vide cooked green beans (Phaseolus vulgaris). Department of Dairy and Food Science, 1997, 205(5): 370-374.

https://link.springer.com/article/10.1007/s002170050183

Laakkonen E., Wellington G.H. \& Sherbon J.W. Lowtemperature, long-time heating of bovine muscle. Changes in tenderness, water-binding capacity, $\mathrm{pH}$ and amount of water-soluble components. Journal Food Science, 1970, 35: $175-177$.

https://onlinelibrary.wiley.com/doi/abs/10.1111/j.13652621.1970.tb12133.x

Levy P. A taste of technology. Observer Magazine, 1986: 58-60.

https://www.sciencedirect.com/science/article/pii/0956713 59591453R

Manser S. Comparing notes. Taste November, 1988, 16. https://www.sciencedirect.com/science/article/pii/0956713 $\underline{59591453 \mathrm{R}}$

Mortensen L. , Frøst M. Leif H. Skibsted \& Risbo R. Effect of time and temperature on sensory properties in lowtemperature long-time sous-vide cooking of beef. Journal of Culinary Science \& Technology, 2012, 10, 1. https://doi.org/10.1080/15428052.2012.651024 
Myhrvold N., Young C. \& Bilet M. Modernist cuisine, the art and science of cooking, history and fundamentals. Bellevue, WA: The Cooking Lab., 2011a, 1.

http://citeseerx.ist.psu.edu/viewdoc/download?doi=10.1.1. $\underline{858.5638 \& \mathrm{rep}=\mathrm{rep} 1 \& \text { type }=\mathrm{pdf}}$

Myhrvold N., Young C. Bilet M. Modernist cuisine, the art and science of cooking, Techniques and equipment. Bellevue, WA: The Cooking Lab., 2011b, 2.

http://citeseerx.ist.psu.edu/viewdoc/download?doi=10.1.1. $\underline{858.5638 \& \mathrm{rep}=\mathrm{rep} 1 \& \text { type }=\mathrm{pdf}}$

Nishimura K., Miyamoto Y. \& Higasa T. Tenderer chicken breasts vacuum-cooked at $75^{\circ} \mathrm{C}$. Journal of Home Economics of Japan, 2004, 55(8): 605-615 https://www.jstage.jst.go.jp/article/jhej1987/55/8/55 $8 \quad 60$ 5/pdf

Nyati H. An evaluation of the effect of storage and processing temperatures on the microbiological status of sous vide extended shelf-life products. Food Control Volume, 2000, 11(6): 471-476.

https://doi.org/10.1016/S0956-7135(00)00013-X

Oh K.S., Kim H.Y. \& Ko S.H. Evaluation of the quality of simmered chicken in soy sauce prepared with the sous vide cook-chill system and conventional cook-chill system. Korean Journal Food Cookery Science, 2006, (23): 617-625.

http://www.koreascience.or.kr/article/ArticleFullRecord.js p?cn=HJRGB8 2006 v22n5s95 617

Patras A., Brunton N.P. \& Butler F. Effect of water immersion and sous-vide processing on antioxidant activity, phenolic, carotenoid content and color of carrot disks. Journal of Food Processing and Preservation, 2009, 34: 1009-1023.

https://doi.org/10.1111/j.1745-4549.2009.00434.x

Picouet P.A., Cofan-Carbo S. \& Vilaseca H. Stability of sous-vide cooked salmon loins processed by high pressure. Innovative Food Science and Emerging Technologies, 2011, 12: 26-31.

https://doi.org/10.1016/j.ifset.2010.12.002

Rawson A., Koidis A., Rai D.K., Tuohy M. \& Brunton N. Influence of sous vide and water immersion processing on polyacetylene content and instrumental color of parsnip (Pastinaca sativa) Disks. Journal of Agricultural and Food Chemistry, 2010, 58: 7740-7747. https://pubs.acs.org/doi/abs/10.1021/jf100517p

Renna M., Gonnella M., Giannino D. \& Santamaria P. Quality evaluation of cook-chilled chicory stems (Cichorium intybus L., Catalogna group) by conventional and sous vide cooking methods. Journal Science Food Agriculture, 2014, 94: 656-665.

https:/www.ncbi.nlm.nih.gov/pubmed/23847094

Roca J. \& Bruges S. Sous vide cuisine. Montagud, 2005. https://isnn2017.org/joan-roca-cookbook

Roldán M., Antequera T., Martín M., Mayoral A. \& Ruiz J. Effect of different temperature-time combinations on physicochemical, microbiological, textural and structural features of sous-vide cooked lamb loins. Meat Science, 2013, 93(3): 572-578.

https://doi.org/10.1016/j.meatsci.2012.11.014

Roldán M., Ruiz J., Pulgar J.S., Pérez-Palacios T. \& Antequera T. Volatile compound profile of sous-vide cooked lamb loins at different temperature-time combinations. Meat Science, 2015, 100(1): 52-57. https://www.ncbi.nlm.nih.gov/pubmed/25306511

Sampaio G.R., Saldanha T., Soares R.A. M. \& Torres E.A. Effect of natural antioxidant combinations on lipid oxidation in cooked chicken meat during refrigerated storage. Food Chemistry, 2012, 135, 1383-1390.

https://www.ncbi.nlm.nih.gov/pubmed/22953870

Schafheitle J.M. The sous vide system for preparing chilled meals. British Food J., 1992, 92(1): 23-27. https://www.emeraldinsight.com/doi/abs/10.1108/0007070 $\underline{9010139427}$

Schellekens M. New research issues in sous-vide cooking. Trends in Food Science and Technology, 1996, (7): 256262.

http://www.pasqualepetrilli.it/Didattica/Tecnologia/BiblioTe cnol/hurdle9.pdf

Shakila R.J., Jeyasekaran G., Vijayakumar A. \& Sukumar D. Microbiological quality of sous- vide cook chill fish cakes during chilled storage $\left(3^{\circ} \mathrm{C}\right)$. Food Science, 2009, 44: 11 .

https://doi.org/10.1111/j.1365-2621.2009.02047.x

Sheard M.A. \& Rodger C. Optimum heat treatments for 'sous vide' cook-chill products. Food Control, 1995, 6(1): 53-56.

https://doi.org/10.1016/0956-7135(95)91454-S

Simpson M.V., Smith J.P., Dodds K., Ramaswamy H.S., Blanchfield B. \& Simpson B.K. Challenge studies with Clostridium botulinum in a sous-vide spaghetti and meatsauce product. Journal of Food Protection, 1995, 58(3): 229-234.

https://doi.org/10.4315/0362-028X-58.3.229

Smith D.B. \& Fullum-Bouchard L. Comparative nutritional, sensory and microbiological quality of a cooked chicken menu item produced and stored by cook/chill, cook/freeze and sous vide cook/chill methods. Poster presented at Canadian Dietetic Association Annual Conference, 1990, 7, 6.

https://www.sciencedirect.com/science/article/pii/0956713 59591453R

Snyder Jr OP. HACCP and Regulations Applied to Minimally Processed Foods. Microbial Safety of Minimally Processed Foods: CRC Press., 2003.

Souza M.L.R. Comparison of six filleting methods and their relation with fillet yield and by-products of nile tilapia (Oreochromis niloticus) processing. Brazilian Journal Animal Science, 2002, 31: 1076-1054. http://dx.doi.org/10.1590/S151635982002000500003 
Sun X.D. \& Holley R.A High hydrostatic pressure effects on the texture of meat and meat products. Journal Food Science, 2010, 75(1): 17-23.

https://onlinelibrary.wiley.com/doi/abs/10.1111/j.17503841.2009.01449.

Tornberg, E. Effect of heat on meat proteins - implications on structure and quality of meat products. Meat Science, 2005, 70: 493-508. https://doi.org/10.1016/j.meatsci.2004.11.021

Vaudagna S.R., Sanchez G., Neira M.S., Insani E.M., Picallo A.B., Gallinger M.M. \& Lasta J.A. Sous vide cooked beef muscles: Effects of low temperature-long time (LT-LT) treatments on their quality characteristics and storage stability. International Journal Food Science Technology, 2002, 37(5): 425-441.

https://onlinelibrary.wiley.com/doi/abs/10.1046/j.13652621.2002.00581.x

Vijay K., Benne J. \& Marmer S. Growth of Clostridium perfringens from spore inocula in sous-vide turkey products. International Journal of Food Microbiology, 1996, 32(1-2): 115-123. https://doi.org/10.1016/0168-1605(96)01111-7

Wang S.H., Chang M.H. \& Chen T.C. Shelf-life and microbiological profiler of chicken wing products following sous vide treatment. Journal of Poultry Science, 2004, 3(5): 326-332.

http://docsdrive.com/pdfs/ansinet/ijps/2004/326-332.pdf

Werlein H.D. Comparison of the quality of sous-vide and conventionally processed carrots. Zeitschrift für Lebensmitteluntersuchung und -Forschung A., 1998, 207: 311-315. https://link.springer.com/article/10.1007/s002170050338

Werner R. Vitamin loss during cooking in LTLT-meat. Danish tehnological university, Practical semster, 2016. https://link.springer.com/article/10.1007/s12393-016$\underline{9143-5}$ 